\title{
The Social Hubs project: exploratory real-world research - students as researchers and experiential learning
}

\section{Carin Tunåker}

University of Kent, UK

Ian Bride

University of Kent, UK

Daniela Peluso

University of Kent, UK

\section{Abstract}

This case study describes an experiential approach to teaching and learning that has been successfully employed at the University of Kent. It offers a way for engaging students across disciplines in real-world research and in situ learning experiences that allow them to build various skills sets and take on responsibilities whilst making a valuable contribution to their university community. The Social Hubs project, akin to approaches such as Participatory Action Research (PAR) and including 'students as researchers', employed anthropological methods for gaining valuable insights about social space on a university campus while also providing key student learning experience and careerbuilding employment.

Keywords: real-world research; experiential learning; learning engagement; student experience; campus as classroom; applied anthropology.

\section{Introduction}

The roots of experiential learning run deep, drawing on the ground breaking work of John Dewey, Kurt Lewin, Jean Piaget, and subsequently, David Kolb. There is now an impressive body of literature supporting the value of such learning initiatives, such as 'inquiry based learning' (Healey, 2005) and also the 'student as producer' movement 
(Neary and Winn, 2009). Kolb (1984) describes experiential learning as the individual learner's progression from apprehension to comprehension and provides considerable evidence for the value of extra-curricular inquiry activity in skills development (see also Healey and Jenkins, 2000). Although substantial benefits often accrue to the students in terms of skills and knowledge, as Wood et al. (2011, p.17) argue, the impact can transcend personal development to the advantage of the organisation as a whole, with students becoming more reliable, responsible and better motivated, so as to allow them '...to take on the role of full partners in the educational development enterprise'.

The Social Hubs project was a research initiative conducted between 2008-2011 on the University of Kent's Canterbury and Medway campuses by members of the School of Anthropology and Conservation, in collaboration with the School of Architecture. It was financed by the university and supported by the 'Creative Campus' initiative (see Bride et al., 2013), an initiative that seed-funds learning and teaching innovations by students or staff. The overarching aim of the Social Hubs project was to develop an overview of existing and potential 'social hubs', which we defined as any indoor or outdoor space where people tend to gather. The principle objective was to identify and define such spaces and to generate guidelines and interventions that would maximise their benefits across the different campus communities. In sum, the project sought to provide data that would inform actual and proposed changes to spaces in the built and non-built environments on two of the University of Kent's campuses. However, in approaching it as an experiential learning and teaching opportunity, both the 'hubs' research, along with those projects subsequently informed by it, sought to set students at the heart of the design and implementation of research and creative activities focused on precipitating meaningful positive changes to the university's physical environment. The expectation was that this would help develop valuable skills, improved motivations and a sense of belonging amongst the student researchers.

The following case study provides a background to the 'Social Hubs' project, its planning, methodology, execution, results and subsequent outcomes, as well as insights into the student learning experience and the wider significance of this project. We briefly discuss the position of this research in relation to Participatory Action Research and other relevant approaches to practice-based learning, although the primary intention of this case study is to outline the practical and learning outcomes of the Social Hubs project, rather than to provide in-depth analysis that relates to previous research. 


\section{Methodology}

In the Autumn of 2008, the Head of the School of Anthropology and Conservation, sitting on a committee discussing proposed estate developments, posited the idea of conducting research to better understand campus spaces and thereby inform and enlighten future development plans. The university management supported the idea and provided funds that enabled the project to employ students from the School of Anthropology and Conservation and the School of Architecture. The Social Hubs project employed anthropological research methods, including observations, mapping, semi-structured interviewing and field diaries - what a social anthropologist would use during 'fieldwork' (see for example Watson, 1999; Bernard, 2006; Okely, 2012). The data collection and development of research methods in the duration of the project was a student-led process. It employed a combination of quantitative and qualitative methods at each stage of research, using conventional social science approaches. The findings then informed the subsequent research foci, such as the development of the targeted interviews. Employing students as paid researchers enabled them to participate fully in the research process and be trained in formulating and applying a mixed methods approach that included ethnographic research, interviews, and other survey instruments, such as movement diaries and mapping. This onsite training allowed students to incorporate a valuable skillsbased training element within a context of a real-world, dynamic, experiential learning exercise. Apart from privileging experiential learning, the adoption of an iterative approach in the research process, and the application of several established research methods and survey instruments, the project was not informed by a specific theoretical perspective. Nor did it involve the application of an established framework for student engagement, but rather the framework for theory and engagement arose from the ongoing reflection over the project and its outcomes.

The data analysis, however, was left for senior staff of the project - with the exception of Carin Tunåker, who took part in the data analysis and presentation of the results for the Medway campus - as it would have required significant training and experience for the students to participate appropriately; a resource we unfortunately neither had the time nor funding to provide. In adopting an iterative approach, whereby findings from each stage informed subsequent research directions, the first activity was to observe behaviour in a broadly representative sample of hubs. For this purpose, fifteen undergraduate students 
were recruited into five teams, each allocated a distinct area of the campus and each managed by a postgraduate team leader who also collated the data.

The project survey methodology was partly framed by the staff team, but was formulated in collaboration with the student researchers in a series of workshops where students went through practical and brainstorming exercises to develop an appropriate research design. The student teams began their fieldwork by making general observations of currently busy hubs and less obvious spaces in non-busy areas, as well as identifying potential development ideas. They mapped the designated areas, recording movement patterns through them, and completed a field diary, whilst also developing ideas as to what the most appropriate methods and survey instruments would be for the second research stage.

Having compiled and reviewed the observations made in stage one, the teams undertook in-depth observations of the busiest hubs in their designated areas. They thoroughly mapped each area making direct observations of usage. Depending on the general level of occupation, either one or two students made observations at different fixed time slots in the morning, lunchtime, afternoon and, in some cases, evening periods as well. Utilisation patterns were mapped out noting gender, approximate age group and activities of users, as well as their physical location within the hub. Photographs were used to back up written records, and circumstantial factors taken into consideration, such as weather conditions, campus events etc. Throughout the process, students provided input as to how well the methods worked, which they thought to have yielded the most useful data, and they also formed and presented their own opinions. These latter data included student field diaries, where they had free rein to reflect and present their thoughts in whichever way they wished.

The final stage of the Canterbury research gathered a body of qualitative data, with team leaders and staff team members conducting semi-structured interviews with staff and students. Some of these interviews were randomly selected within allocated buildings and hubs, whereas others targeted specific members of staff in several university buildings.

In 2010, the research was replicated at the university's Medway campus. Here, with rather fewer spaces to survey, just one team of four students was recruited, led by Tunåker, who had been a team leader on the Canterbury study and promoted to the role of project officer 
for the Medway study. Although using the methodology we had established, these students also discussed survey methods and made changes to the subsequent data gathering process, thereby continuing the project's student-learning focus.

\section{Findings and impact: influencing changes to people and places}

The Social Hubs research generated a substantial amount of data, of both a quantitative and qualitative nature, which were explored both individually and in discussion by the project team. Since the core aim of the Social Hubs research was to influence decisionmaking in regards to these spaces, pragmatic suggestions for improvements and new developments were the primary focus of analysis. The research clearly proved highly valuable in revealing ways in which people use and perceive existing hubs, and their needs and desires for improvements and additional provision. For example, issues regarding poor acoustics in some of the campus eateries were identified and subsequently adjusted, as well as a pressing need for external seating areas on the campus and updating of indoor areas that had appeared unwelcoming and out-dated.

After the research data had been analysed, compiled, and presented to the appropriate planning and development committees, real-world outcomes became visible in the shape of significant changes to parts of the built and non-built environment. In response to the project findings, the university allocated quite substantial resources to a social spaces fund which, in its first two years of operation, was used to develop significant improvements on the Canterbury campus (the Medway research had yet to be carried out). This included an outdoor teaching space (dubbed 'Quercus genius'), and a café/flexible learning/teaching space that integrated into an MA Architecture design module and used a student, PierLuigi del Renzio, as part of the construction team. Del Renzio commented that the result showed '...the true realisation of a student-based project which is now being built before our very eyes'.

The other key objective of the project, to develop students' research skills in a real-world situation, was also realised. Students acquired valuable employability skills and increased their self-confidence in tackling solution-driven research by actually seeing the results of their thinking as outlined by their research and practice. This can also be seen as an important lesson that can enhance student employability. The practical heart of the project 
enabled them to experience anthropological fieldwork first-hand and get an understanding of the importance of mixed research methods, the types of the data they produce, and the types of results they yield. Moreover, the students were able to appreciate the real-world contributions they made to the broader university community, as well as the experiential learning that resulted in their having been given a say in the design of their own learning environment, both in regards to project methodologies and subsequent developments in 'bricks and mortar'. As Laura, one of the postgraduate team leaders reflected:

The Social Hubs research was an invaluable experience for me, and something that I really enjoyed. I already knew that I loved doing interviews from my anthropology coursework, but this was a taste of how to put that love and skill in to the real world. Knowing that the work I conducted would go towards research to benefit students was such a confidence boost, and I am so proud to have been a part of it. Plus it looks great on my C.V. and is a real conversation piece! (Laura, MA Social Anthropology, 2009)

In regards to the projects that were precipitated by the Social Hubs research, Grace, a $3^{\text {rd }}$ year BSc Wildlife Conservation and Management student, who participated in the 'Quercus genius' project, stated:

I thought having a new, green-learning space was a wonderful idea! It will be great to encourage especially environmental classes to be taught outside, as well as creating a social area for people to congregate and enjoy more of the green-ness of campus. We could certainly replicate this elsewhere on campus. I enjoyed the teamwork, and learnt to remove bark with a chisel! + a lot of general problemsolving skills, such as collectively moving a really heavy branch up a hill. It made me feel happy and proactive! (Grace, BSc Wildlife Conservation and Management, 2010)

Although a specific educational theoretical model was not articulated for the project, clearly the iterative approach we adopted for the design and the execution of the original project, as well as for some of the new developments it precipitated, had quite profound learning impacts on the student participants. In addition to the research design and data collection/organisation skills they acquired, student participants also boosted their team- 
working skills, and for team leaders, further skills associated with managing groups were also attained.

\section{Students as researchers}

The Social Hubs project was as experiential as it was experimental, encompassing methods and approaches drawn from across the disciplines of anthropology, conservation and architecture. A principal method adopted for the project and some of its progeny bears similarities to established 'Action Research' (AR) methods (see, for example, Wadsworth, 1998; Kemmis and McTaggart, 2000; Cousin, 2009; Cohen et al., 2011). Action Research is a paradigm of inquiry wherein the researcher's primary objective is to improve the capacity and subsequent practices of the researcher, rather than simply produce and test theoretical knowledge (Elliott, 1991). It is not unusual for Action Research not to have preset aims or objectives; its goals are aimed toward improving the skills of those involved in the process of the research rather than toward producing specific knowledge outcomes. Since this research was oriented at the production of knowledge with specific outcomes in mind, it is perhaps more akin to a form of 'Participatory Action Research' (PAR), where researcher and participants collaborate actively to study and change their social reality, and where the aim is for collective learning such that the researcher has less control over the research design (Wadsworth, 1998). However, bona fide Participatory Action Research would have entailed close monitoring of the results of the changes precipitated and the ensuing formulation, plus the application of new methods and objectives. Unfortunately, our own resources and ability to follow-up were limited once the main project and its offspring had been completed.

Upon reflection, the Social Hubs project might be understood as approximating the idea of threshold concepts and research partnerships approach advocated by Cousin (2010). A 'threshold concept' is characterised by being: transformative, in the sense that the learner assimilates new learning as part of who they are; irreversible, in that this learning is robustly internalised; and integrative, in that during the process the learner is able to make connections across the different understandings they bring to and develop in the learning space (Cousin, 2010). In this instance, the professional and disciplinary development of Tunåker who moved across thresholds from student team leader, through project officer, to co-author of this paper, might be seen to epitomise this approach. She 
'became' a Social Hubs researcher and project manager, and was able to bring together, consolidate, articulate, and build upon a wide range of knowledge and understandings she had developed during her undergraduate and postgraduate studies.

Whichever theoretical model best describes our approach, we firmly believe that what we have achieved in terms of precipitating changes to physical environments and enhancing learning experiences, understandings of research, and employability skill sets, was highly valuable to the students involved. As such, and in new iterations within and adjacent to the formal curriculum, the project approach offered opportunities for the non-conformist approach advocated by Derounian (2011) and addressed the calls for student empowerment and participation made by Kay et al. (2010). It also exhibited a close similarity to the three-dimensional approach to student engagement advocated by the $\mathrm{HE}$ Academy in its framework for 'Students as Partners', namely, to incorporate engaged learning and research, and involve students as change agents, both in respect to learning and teaching enhancement, and to the institution more widely (HE Academy, 2013, and see also Neary and Winn, 2009). Indeed, it can not only be understood as having met most of the detailed principles this framework advocates, but also to correlate with the conceptual framework set out by Trowler and Trowler (2010), such that the impact of this student engagement was highly salient to the aspirations of our institution, very much in character (congruent) with the physical and intellectual spaces offered by the university, and of benefit to a range of groups representing different communities and groups (profitability).

\section{Conclusion}

Teaching and learning anthropology are cultural processes that dialogically share and produce knowledge (Freire, 1997). This project has encouraged students to think widely and critically about their own position in the university, society and the world, thus preparing them for broader significant issues within anthropology, conservation, architecture and across disciplines.

Overall, this Social Hubs project demonstrates how, when students are given the means and opportunities to engage in practice-based learning related to their discipline and local challenges within their immediate university environment, this can benefit all parties 
involved. The project itself advocates exploration and innovation in all pedagogical aspects; students developing individual approaches to different methodologies, testing them in real settings and learning from the process, as well as seeing actual results stem from their work and thereby achieving significant learning outcomes. This gave all participants a satisfying and real sense of achievement, and it provided a novel learning experience that was embedded through practice and will outlast their tenure as students. Since completion of the Social Hubs project, the outcomes have been published in the Student Engagement Handbook (Bride et al., 2013), and the Creative Campus initiative continues to seek student consultation to improve and adapt social space at the University of Kent. For instance, it is currently supporting Bride and students in the creation of a coppice crafts production site within the campus woodland (Spring 2015).

\section{Acknowledgements}

The authors would like to thank the University of Kent for funding and supporting the Social Hubs research, and for implementing some of its recommendations, as well as to the Creative Campus initiative and Louise Naylor. Special thanks are also due to Professor Bill Watson, former Head of the School of Anthropology and Conservation, who championed and spearheaded the project's initiation; with important help contributed by Miles Berkley. Acknowledgement should also be made of the project advisory team of staff (Ian Bride, Daniela Peluso, Melissa Demian and Chris Gardner), and of Ian Bride and Carin Tunåker, who respectively managed the Social Hubs research at Canterbury and at Medway. We would also like to thank the LDHEN article referees for their constructive feedback and bringing to our attention additional valuable reference materials. Of course we are most indebted to the undergraduate and postgraduate students who so enthusiastically gave their time, energy and insights to this initiative. We hope that they all benefitted from and enjoyed the experience as much as we did.

\section{References}

Bernard, H.R. (2006) Research methods in anthropology: qualitative and quantitative approaches. Lanham: Alta Mira Press. 
Bride, I., Naylor, L. and Tunåker, C. (2013) 'The creative campus: empowering the university community to change spaces', in Dunne, E. (ed.) The student engagement handbook: practice in higher education. Bingley: Emerald Group Publishing Ltd, pp. 255-269.

Cohen, L., Manion, L. and Morrison, K. (2011) Research methods in education. London: Routledge.

Cousin, G. (2009) Researching learning in higher education: an introduction to contemporary methods and approaches. London: Routledge.

Cousin, G. (2010) 'Neither teacher-centred nor student-centred: threshold concepts and research', Journal of Learning Development in Higher Education, Issue 2, February, pp. 1-9.

Derounian, J. (2011) 'Fanning the Flames of non-conformity', Journal of Learning and Development in Higher Education, Issue 3, pp. 1-6.

Elliot, J. (1991) Action Research for educational change. Buckingham: Open University Press.

Freire, P. (1997) Pedagogy of the Oppressed. London: Continuum International Publishing Group Ltd.

HE Academy (2013) Students as Partners Work webpage. Available at: http://www.heacademy.ac.uk/students-as-partners-work (Accessed: 22 November 2013).

Healey, M. (2005) 'Linking research and teaching: exploring disciplinary spaces and the role of inquiry-based learning', in Barnett, R. (ed.) Reshaping the university: new relationships between research, scholarship and teaching. McGraw Hill /Open University Press, pp. 67-78. 
Healey, M. and Jenkins, A. (2000) 'Learning cycles and learning styles: the application of Kolb's experiential learning model in higher education', Journal of Geography, 99(5), pp. 185-95.

Kay, J., Dunne, E. and Hutchinson, J. (2010) Rethinking the values of higher educationstudents as change agents? Gloucester: QAA. Available at:

http://www.qaa.ac.uk/en/Publications/Documents/Rethinking-the-values-of-highereducation---students-as-change-agents.pdf (Accessed: 1 March 2015).

Kemmis, S. and McTaggart, R. (2000) 'Participatory action research', in Denzin, N.K. and Lincoln, Y.S. (eds.) Handbook of qualitative research. 2nd edn. Thousand Oaks CA: Sage, pp. 567-605.

Kolb, D. (1984) Experiential learning: experience as the source of learning and development. New Jersey: Prentice Hall.

Neary, M. and Winn, J. (2009) 'The student as producer: reinventing the student experience in higher education', in Bell, L., Stevenson, H. and Neary, M. (eds.) The future of higher education: policy, pedagogy and the student experience. London: Continuum, pp. 192-210.

Okely, J. (2012) Anthropological practice: fieldwork and the ehnographic method. London/New York: Berghahn Books.

Trowler, V. and Trowler, P. (2010) Framework for action: enhancing student engagement at the institutional level. Available at: https://www.heacademy.ac.uk/sites/default/files/resources/Frameworkforaction insti tutional.pdf (Accessed: 1 March 2015).

Wadsworth, Y. (1998) 'What is participatory action research?', Action Research International, Paper 2 [Online]. Available at: http://www.aral.com.au/ari/pywadsworth98.html (Accessed: 6 June 2014).

Watson, B. (1999) Being there: fieldwork in anthropology. London: Pluto Press. 
Wood. J. P., Little, S., Goldring, L. and Jenkins, L. (2011) 'The confidence to do things that I know nothing about' - skills development through extra-curricular inquiry activity. Journal of Learning Development in Higher Education, Issue 3, pp. 2-21.

\section{Author details}

Carin Tunåker is currently progressing her doctoral research in social anthropology at the University of Kent, where she aims to investigate the conditions and circumstances that contribute toward LGBT youth homelessness in Kent through the use of in-depth ethnography. Other research interests include gender, sexuality and home in different localities, with published work on Cuba. She is also the co-founder and director of the Home and Sexuality Research Network.

Dr lan Bride (corresponding author) is a Senior Lecturer in Bodiversity Management in the School of Anthropology and Conservation, University of Kent, where he teaches undergraduate modules: Guiding and Interpretation; and Creative Conservation. He has been involved with the creative projects on the university campus for many years, collaborating closely with the Unit for the Enhancement of Learning and Teaching, and acted as project manager on the Social Hubs project.

Dr. Daniela Peluso is a sociocultural anthropologist whose research interests range from Amazonian to corporate environments. Her teaching brings together divergent and similar aspects of the 'exotic' and ordinary, global and local for a contemporary understanding of and approach toward social anthropology. She is a Senior Lecturer in Social Anthropology at the University of Kent. 